\title{
Soil Conservation Service Curve Number: How to Take into Account Spatial and Temporal Variability
}

\author{
M.Rianna ${ }^{\mathrm{a}}$, D.Orlando ${ }^{\mathrm{b}}$, V. Montesarchio ${ }^{\mathrm{c}}$, F.Russo ${ }^{\mathrm{b}}$, F.Napolitano $^{\mathrm{b}}$ \\ ${ }^{a}$ Centro Reatino di ricerche di Ingegneria per la Tutela e la Valorizzazione dell'Ambiente e del Territorio, Sapienza \\ Universitàdi Roma, Rieti, Italy, email: maura.rianna@uniromal.it \\ ${ }^{b}$ Dipartimento di Ingegneria Civile, Edile e Ambientale, Sapienza Università di Roma, Rome, Italy \\ ${ }^{c}$ Centro Interuniversitario di Formazione Internazionale H2CU-Honors Center of ItalianUniversity, Rome, Italy
}

\begin{abstract}
The most commonly used method to evaluate rainfall excess, is the Soil Conservation Service (SCS) runoff curve number model. This method is based on the determination of the $\mathrm{CN}$ valuethat is linked with a hydrological soil group, cover type, treatment, hydrologic condition and antecedent runoff condition. To calculate the antecedent runoff condition the standard procedure needs to calculate the rainfall over the entire basin during the five days previous to the beginning of the event in order to simulate and then to use that volume of rainfall to calculate the antecedent moisture condition (AMC). This is necessary in order to obtain the correct curve number value. The value of the modified parameter is then kept constant throughout the whole event.

The aim of this work is to evaluate the possibility of improving the curve number method.The various assumptions are focused on modifying those related to rainfall and the determination of an AMC condition and their role in the determination of the value of the curve number parameter.In order to consider the spatial variability we assumed that the rainfall which influences the $\mathrm{AMC}$ and the $\mathrm{CN}$ value does not account for the rainfall over the entire basin, but for the rainfall within a single cell where the basin domain is discretized. Furthermore,in order to consider the temporal variability of rainfall we assumed that the value of the $\mathrm{CN}$ of the single cell is not maintained constant during the whole event, but instead varies throughout it according to the time interval used to define the AMC conditions.
\end{abstract}

Keywords:SCS CN, AMC Condition, Runoff Excess, Spatial and Temporal Variability.

PACS:96.12.ka

\section{INTRODUCTION}

A hydrologic model is an approximation of the reality; its inputs and outputs are hydrologic variables and its structure is a set of equations relating to inputs and outputs. These models are generally calculated numerically andallow an estimate for the amount of flooding and drought that occurs through a temporal and spatial hydrological system.

One of the most usedhydrologic modelsforexcess rainfall is the curve number method that was developed by the USDA Natural Resources Conservation Service, (SCS) and is still identified in the literature as the "SCS runoff curve number"[1].

The curve number value is a function of the area's hydrologic soil group, land use and hydrologic condition.

The literature has studied this topic widely and many studies have investigated the benefits and limitations of the $\mathrm{CN}$ and how to improve it $[2,3,4,5]$. The most important advantages of the method is represented by its simplicity and quickness, but the most important disadvantages are represented by the absence of an explicit provision for spatial and temporal scale effects. In this work, we propose a simple modification to improve curve number procedures and to solve this problem.

The $\mathrm{CN}$ values are strictly related to the soils saturation level, and this dependence is expressed by the antecedent moisture condition (AMC). The standard $\mathrm{CN}$ method calculates the rainfall over the entire basin during a five day period priorto the beginning of the event in order to evaluate the AMC conditions. This is necessary to obtain the correct curve number values, which are then kept constant throughout the whole event. In this way, the entire basin changes its $\mathrm{AMC}$ conditions in a uniform manner, and consequently, the $\mathrm{CN}$ changes in a uniform manner as well.

The hypothesis of this work is that the AMC conditions do not change in an uniform way, but instead depend on the rainfall from a single cell where the basin is discretized.Through this, we can take into account the spatial variability of the rainfall event, and the spatial variability of the $\mathrm{CN}$ value. Furthermore, to consider the temporal variability of the rainfall, the AMC condition of each cell is changed during the event, where the $\mathrm{CN}$ also changes.

Numerical Analysis and Applied Mathematics ICNAAM 2012

(C) 2012 American Institute of Physics 978-0-7354-1091-6/\$30.00 
This takes into better account the spatial and temporal variability of the runoff process and has wide application in different fields of hydrological science, from urban applications $[6,7]$ to ephemeral catchment hydrology [8].

\section{THE CURVE NUMBER METHOD}

\section{CN equations}

The $\mathrm{CN}$ method is founded on the water balance equation and on two hypotheses. The first hypothesis assumes that, in a flood, the actual amount of direct runoff divided by the maximum potential runoff is equal to the ratio of the amount of actual infiltration versus the potential maximum retention.

$$
P=I_{a}+F+Q \quad ; \quad \frac{Q}{\left(P-I_{a}\right)}=\frac{F}{S}
$$

Where $P=$ total precipitation, $I_{a}=$ initial abstraction, $F=$ cumulative infiltration, $Q=$ direct runoff, $S=$ potential maximum retention or infiltration and $\lambda=$ initial abstraction ratio.

The second hypothesis assumes that the amount of initialabstraction hasa linear relationship [1]with the potential maximum retention $\left(I_{a}=\lambda S\right)$.

The first two equations in Eq. 1 combined, cause Eq. 2:

$$
\mathrm{Q}=\frac{\left(\mathrm{P}-\mathrm{I}_{\mathrm{a}}\right)^{2}}{\left(\mathrm{P}-\mathrm{I}_{\mathrm{a}}+\mathrm{S}\right)}
$$

For convenience, in practical applications, $S$ is related to a dimensionless parameter $C N$, the curve number. This varies in the range of: $0<C N<100$. The relationship is expressed by:

$$
\mathrm{CN}=100 \cdot\left(\frac{\mathrm{S}_{0}}{\left(\mathrm{~S}_{0}+\mathrm{S}\right)}\right)
$$

The CN2 associated with AMC2(moisture average condition) is the standard curve number given in the SCS and other relevant tables [1]. The low and high values are the dry and wet curve numbers, associated with AMC1 and AMC3 conditions, and are possible to calculate through simple equations.

The level of AMC to use in any given case can be found through the total5-day antecedent rainfall [1].

\section{METHODOLOGY}

In order to have a better representation of hydrological losses, a definition for the curve number classes was needed. In the first step, we focused on the AMC condition and had defined new AMC classes through just a simple mean process.

For every new AMC class, we had defined a corresponding CN value. This wasalways obtained through a simple mean process where these new values were interpolated with a double exponential relation in the form:

$$
\mathrm{CN}=\alpha \cdot \exp [\beta \cdot \mathrm{CN}(\mathrm{II})]+\delta \cdot \exp [\gamma \cdot \mathrm{CN}(\mathrm{II})]
$$

The four coefficient of the (4) and the R-square value are listed in the following table:

TABLE 1. Table of coefficientsof the (5) Equation

\begin{tabular}{llllll}
\hline & $\alpha$ & $\beta$ & $\delta$ & $\gamma$ & R-square \\
\hline CN (I) & 14.25 & 0.0195 & -15.23 & -0.01382 & 0.9994 \\
CN (a) & 19.91 & 0.0164 & -20.66 & -0.01453 & 0.9996 \\
CN (II) & & & & & \\
\hline
\end{tabular}




\begin{tabular}{llllll}
\hline CN (d) & 86.46 & 0.0041 & -85.79 & -0.01019 & 1.0000 \\
CN III & 99.53 & 0.0014 & -97.25 & -0.01918 & 0.9995 \\
\hline
\end{tabular}

In the classic $\mathrm{CN}$ method, the assumptions are that the moisture conditions vary uniformly over the whole basin and that the $\mathrm{CN}$ is constant in time and space during the whole simulation.In order to change these assumption it was decided to consider the rainfall of each cell of the DEM. This means thatevery cell of the DEM will have its particular AMC conditions, and then its particular $\mathrm{CN}$.

For the classic $\mathrm{CN}$ method the curve number at the generic time $t>t_{0}$ depends on the rainfall at the time interval $t_{0}-\tau$ where $t_{0}$ is the start time event.This value is kept constant for the entire duration of the event. Here it was decided that the AMC condition at the generic time $t$, took account of the rainfall during the time interval $t$ - $\tau$. Through this we can consider the time variability of the rain and consequently the time variability of the $\mathrm{CN}$, that now is a CN changing during the event, evaluated for the single cell $(\mathrm{i}, \mathrm{j})$, which alsodependson the space variability of the rainfall.

$$
\mathrm{CN}(\mathrm{i}, \mathrm{j}, \mathrm{t})=\mathrm{f}[\mathrm{AMC}(\mathrm{i}, \mathrm{j}, \mathrm{t}-\tau)]
$$

\section{APPLICATION TO THE MIGNONE BASIN}

The study area is theMignone basin, located North-west of Rome. The basin is characterized by a surface of 500 $\mathrm{km}^{2}$ and the length of the main stream is about $62 \mathrm{~km} .5$ rain gauges was in the study area. Information on land use was taken from the "Corine Land Cover" project.The monitoring network of the Mignone river basin used in this work is formed by four raingauges.

It is possible to see in Fig.1 that while the standard $\mathrm{CN}$ is determined based only on the AMC, and then kept constant, the modified $\mathrm{CN}$ varies during the whole event (Fig.1). It is also interesting to note the spatial difference between the two methods. Clearly, in the standard method, the $\mathrm{CN}$ is uniformly modified, to where, conversely the new procedure is closely related to the rainfall spatial distribution.

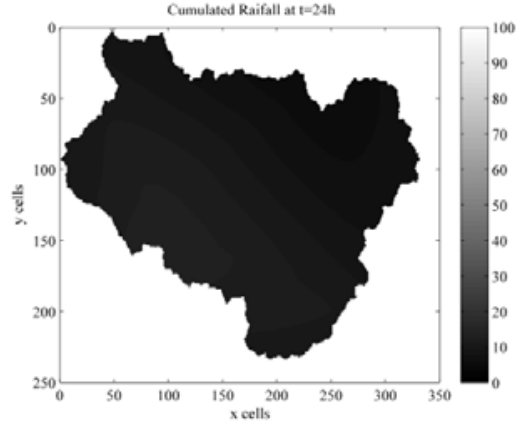

(a)

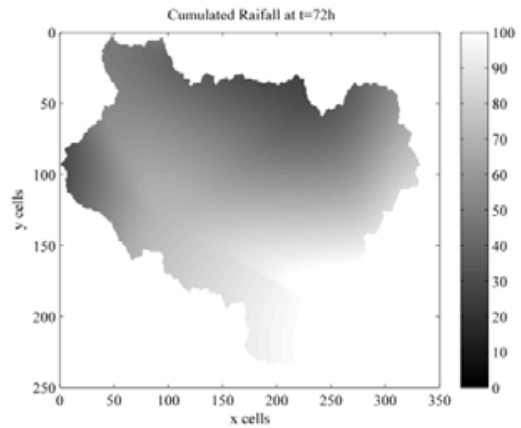

(c)

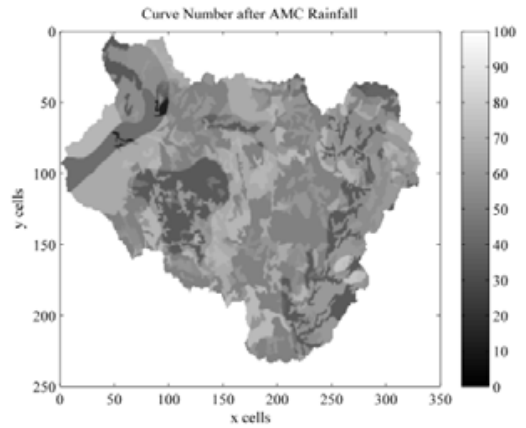

(b)

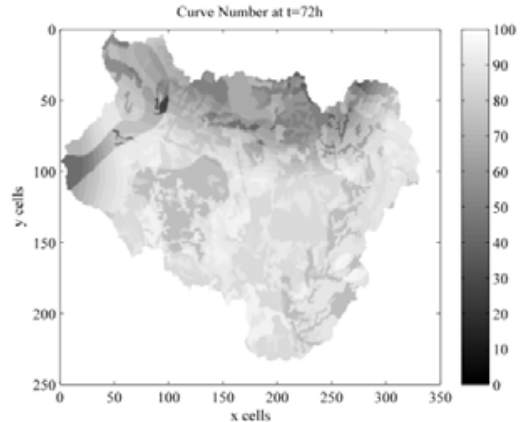

(d)

FIGURE 1.(a) AMC rainfall. (b) $\mathrm{CN}$ after AMC rainfall. (c) Cumulated rainfall after 72 hours. (d) $\mathrm{CN}$ after 72 hours. 
The validity of the model was evaluated based on the results obtained of applying the method in a WFIUH based rainfall runoff model through a Nash and Sutcliffe coefficient (6):

$$
\mathrm{E}=1-\frac{\sum_{\mathrm{t}=1}^{\mathrm{T}}\left(\mathrm{Q}_{0}^{\mathrm{t}}-\mathrm{Q}_{\mathrm{m}}^{\mathrm{t}}\right)}{\sum_{\mathrm{t}=1}^{T}\left(\mathrm{Q}_{0}^{\mathrm{t}}-\overline{\mathrm{Q}_{\mathrm{m}}}\right)}
$$

where $\mathrm{Q}_{0}$ is the observed discharge, and $\mathrm{Q}_{\mathrm{m}}$ is a modeled discharge, $\mathrm{Q}_{0}^{\mathrm{t}}$ is an observed discharge at time $t$ and $\overline{\mathrm{Q}}_{\mathrm{m}}$ is the average model's discharge. It was calculated alsothe percentage differences on the hydrograph peaks.

Results of the two methods, both obtained without calibration, show that the proposed method gives better results ( Table 2).

TABLE 2. Results of an application of the proposed and standard method in a rainfall-runoff model

\begin{tabular}{llllllll}
\hline \multirow{2}{*}{$\begin{array}{l}\text { Event } \\
\text { Date }\end{array}$} & $\mathbf{Q}_{\max }\left[\mathbf{m}^{3} / \mathbf{s}\right]$ & Season & $\lambda$ & $\mathbf{E}\left(\mathbf{C N}_{\text {new }}\right)$ & $\Delta \mathbf{Q}_{\max }$ & $\mathbf{E}\left(\mathbf{C N}_{\text {std }}\right)$ & $\Delta \mathbf{Q}_{\max }$ \\
\hline $10 / 04 / 2000$ & 209.3 & III & 0.3 & 0.64 & $0 \%$ & -0.36 & $93 \%$ \\
$07 / 11 / 2005$ & 171.8 & II & 0.3 & 0.70 & $19 \%$ & -0.16 & $94 \%$ \\
$16 / 03 / 2006$ & 209.7 & II & 0.3 & 0.36 & $52 \%$ & -0.36 & $96 \%$ \\
\hline
\end{tabular}

\section{CONCLUSIONS}

The curve number method is commonly used and is a simple and efficient procedure to calculate the amount of direct runoff from a rainfall event. In this work, we proposed a simple modification for improving curve number procedures and for solving the problemsof absence of explicit provision for spatial and temporal scale effects. This would also affects the sensitivity of the methodfor the curve number value.

The results show that with this procedure, we obtained very different $\mathrm{CN}$ values, closely related to the spatial and temporal distribution of precipitation. In particular, it is possibleto obtain high values of $\mathrm{CN}$ only where there is an effectively high volume of rain.Conversely for a period without rainfall in a certain zone of the basin, it is also possible to represent the effects of the absorption of the soil.

\section{REFERENCES}

1. Soil Conservation Service (SCS): Hydrology, National EngineeringHandbook, Supplement A, Sect. 4, Chapt. 10, Washington, D.C.: Soil ConservationService, USDA, 1956.

2. K. Mishra and V.P. Singh, Soil Conservation Service Curve Number (SCS-CN) methodology, Boston MA: Kluwer Academic Publisher, 2003.

3. V. M. Ponce and R. H. Hawkins, "Runoff Curve Number: Has It Reached Maturity?", Journal of Hydrologic Engineering 1,(1996).

4. V. Lopez, F. Napolitano, F. Russo, "Calibration of a rainfall-runoff model using radar and raingauge data" (2005), Advances in Geosciences, 2, pp. 41-46.

5. S. Grimaldi, , A. Petroselli, and N. Romano, "Green-Ampt Curve-Number mixed procedure as an empirical tool for rainfallrunoff modelling in small and ungauged basins" Hydrological Processes,(2012).

6. M.Giulianelli, F.Miserocchi, F. Napolitano, F.Russo, "Influence of space-time rainfall variability on urban runoff',Proceedings of the IASTED International Conference on Modelling and Simulation, 2006, pp. 546-551.

7. F.Lombardo, V.Montesarchio, F.Napolitano, F.Russo, E.Volpi, "Operational applications of radar rainfall data in urban hydrology",IAHS-AISH Publication, 327,2009, pp. 258-265.

8. M.Rianna, F.Russo, F. Napolitano, "Stochastic index model for intermittent regimes: From preliminary analysis to regionalization", Natural Hazards and Earth System Science, 11 (4), pp. 1189-1203, (2011). 